\title{
Phytoplankton nutrient control in the oligotrophic South Pacific subtropical gyre (Tuamotu Archipelago)
}

\author{
Philippe Dufour*, Loic Charpy, Sylvain Bonnet**, Nicole Garcia \\ IRD and CNRS, COM, rue de la Batterie des Lions, F-13007 Marseille, France
}

\begin{abstract}
The identification of the nutrients likely to limit phytoplankton in the Tuamotu Archipelago ocean (South Pacific subtropical gyre) is deduced from DIN $\left(\mathrm{NO}_{3}{ }^{-}+\mathrm{NO}_{2}{ }^{-}+\right.$ $\mathrm{NH}_{4}{ }^{+}, \mathrm{PO}_{4}^{++}$, and $\mathrm{SiO}_{2}$ in situ concentrations and strengthened by the results of 4 other studies on the same area (1) $\oslash_{\text {raxax }}$, the maximum quantum yield of photosynthesis, (2) phytoplankton cell size, (3) nutrient enrichment on natural populations, (4) bacterial biomass and nutrient limitation of bacteria. The low $\oslash_{\max }$ and the small size of phytoplankton support the idea of nutrient control. Low DIN concentrations (mean $=0.02 \mu \mathrm{M}$ ), low average DIN:P-PO ${ }_{4}^{+\omega}$ ratios $=0.3$ at:at, low average DIN: $\mathrm{SiO}_{2}=0.04$ at:at, and significant increases of phytoplankton standing stock and bacterial production after $\mathrm{N}$ enrichments point to $\mathrm{N}$ as the main limiting nutrient. $\mathrm{P}$ is the second limiting nutrient as evidenced by the relative low phosphate concentrations $(0.2 \mu \mathrm{M})$ and by the synergetic effect of DIN $+\mathrm{PO}_{4}{ }^{++}$enrichments. Silicon concentrations appear to limit the proliferation of siliceous taxa as evidenced from its average concentration of $1 \mu \mathrm{M}$ and from the scarcity of diatoms. Natural concentrations of vitamins, Mo, Mn, Fe and chelators are sufficient to support the increase of phytoplankton standing stock induced by $\mathrm{N}$ and $\mathrm{P}$ additions and therefore are not limiting.
\end{abstract}

KEY WORDS: Phytoplankton . Nutrient control South Pacific Central gyre Oligotrophy

The oligotrophic area constitutes more than $75 \%$ of the surface of the world's ocean. Within this vast area, nitrogen has been, for a long time, considered as the limiting nutrient of phytoplankton production and standing stock (Howarth 1988). However, the oligotrophic ocean cannot be considered as homogeneous and other nutrients should control phytoplankton: P (Eppley et al. 1973), Si (Brzezinski \& Nelson 1996), Fe (Lindley et al. 1995). This note presents a comprehensive study on the phytoplanktonic nutrient control in the South Pacific central gyre where the control of

-E-mail: dufour@ird.rio.net

- Deceased June 1996 phytoplankton has never been studied, to our knowledge. It was conducted in the oceanic area of the Tuamotu Archipelago where extremely low concentrations of nutrients are maintained in surface waters by a permanent thermal stratification between 150 and $200 \mathrm{~m}$ depth (Rancher \& Rougerie 1995).

Fisher et al. (1988) argued that concentrations $<K_{\mathrm{s}}$ are associated with reduced uptake rates, potentially lowered enough to reduce phytoplankton growth rates or phytoplankton biomass accumulation. Indeed, in such environments with constant low limiting nutrient supply, nutrient luxury consumption and storage (Droop 1983) are unlikely to occur, and growth depends on the uptake of the limiting nutrients. In this note, we compare the concentrations of the major nutrients $N, P$ and $\mathrm{Si}$, measured in the oceanic area of the Tuamotu Archipelago, with their half-saturation constants for uptake $\left(K_{s}\right)$, reported in the literature. The conclusions issued from these comparisons are improved by the results of 4 other studies in the same area: (1) lightphotosynthesis curves (Pagès pers. comm.), (2) cell size and taxonomic composition of phytoplankton (Charpy \& Blanchot 1998), (3) enrichment experiments (Dufour \& Berland 1999) and (4) nutrient control of bacterial production (Torréton et al. 1998).

Materials and methods. The study took place during 2 oceanographic cruises, Typatoll 3 and Typatoll 4, on the RV 'Alis' in November 1995 and March 1996. Surface water ( $0.5 \mathrm{~m}$ depth) was sampled at 12 oceanic sites located between $15^{\circ} 30^{\circ}-18^{\circ} 30^{\prime} \mathrm{S}$ and $142^{\circ}-$ $145^{\circ} \mathrm{W}$ (Fig. 1). Sampling was done leeward from a small plastic boat and at more than $1 \mathrm{~km}$ away from the RV. Water was sampled in acid-cleaned polyethylene bottles and processed within $1 \mathrm{~h}$.

Analyses for $\mathrm{PO}_{4}{ }^{++}$and $\mathrm{NH}_{4}{ }^{+}$were performed according to Murphy \& Riley (1962) and Koroleff (1969) with a precision of $0.02 \mu \mathrm{M}$. $\mathrm{NO}_{2}{ }^{-}+\mathrm{NO}_{3}{ }^{-}$and $\mathrm{SiO}_{2}$ measurements were done according to Wood et al. 


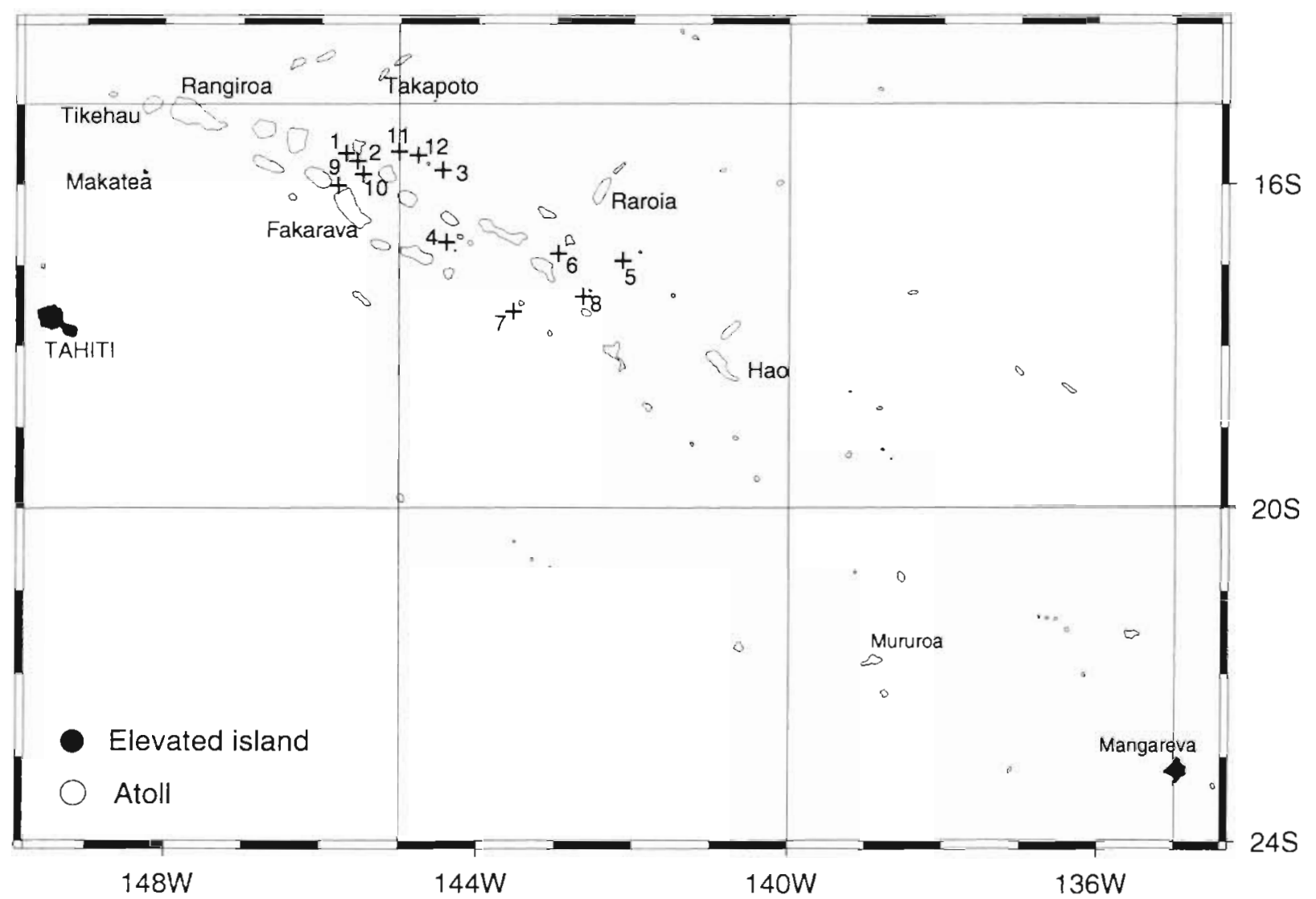

Fig. 1. Location of the 12 ocean sites sampled in the Tuamotu Archipelago (French Polynesia)

(1967) and Mullin \& Riley (1955) with a Technicon autoanalyzer following Tréguer \& Le Corre's (1975) protocol with a precision of $0.01 \mu \mathrm{M}$ for $\mathrm{NO}_{2}^{-}+\mathrm{NO}_{3}{ }^{-}$ and $0.10 \mu \mathrm{M}$ for $\mathrm{SiO}_{2}$

Results and discussion. Evidence of nitrogen limitation from nutrient concentrations in sea water: All the DIN (dissolved inorganic nitrogen) concentrations are $<0.05 \mu \mathrm{M}$ (average $=0.02 \mu \mathrm{M}$, Table 1). Such low DIN concentrations were reported in surface waters of the North Pacific Central gyre and of the South-West

Table 1. Dissolved nutrient concentrations. Mean for all stations, $\mathrm{n}=$ number of samples, $\mathrm{DIN}=$ dissolved inorganic nitrogen

\begin{tabular}{|lllll|}
\hline Nutrient & Unit & Mean & SE & $n$ \\
\hline $\mathrm{NH}_{4}{ }^{+}$ & $\mu \mathrm{M}$ & 0.016 & 0.0041 & 19 \\
$\mathrm{NO}_{2}{ }^{+}+\mathrm{NO}_{3}^{-}$ & $\mu \mathrm{M}$ & 0.010 & 0.0036 & 24 \\
$\mathrm{DIN}^{-}$ & $\mu \mathrm{M}$ & 0.023 & 0.0048 & 19 \\
$\mathrm{PO}_{4}{ }^{++}$ & $\mu \mathrm{M}$ & 0.21 & 0.015 & 24 \\
$\mathrm{SiO}_{2}$ & $\mu \mathrm{M}$ & 1.03 & 0.109 & 24 \\
$\mathrm{DIN}: \mathrm{P}_{-} \mathrm{PO}_{4}^{+{ }^{+}}$ & at:at & 0.14 & 0.028 & 19 \\
$\mathrm{DIN}: \mathrm{Si}$ & at:at & 0.036 & 0.008 & 19 \\
$\mathrm{P}_{-} \mathrm{PO}_{4}{ }^{*}: \mathrm{Si}$ & at:at & 0.24 & 0.022 & 24 \\
\hline
\end{tabular}

Pacific Ocean by Eppley et al. (1973), Perry \& Eppley (1981), and Le Borgne et al. $(1995,1997)$. In the South Pacific subtropical gyre, DIN concentrations reported by Raimbault et al. (1999) at $15^{\circ} \mathrm{S}, 140^{\circ} \mathrm{W}$ were close to 0 (mean $=0.0013 \mu \mathrm{M}, \mathrm{SD}=0.0025 \mu \mathrm{M}, \mathrm{n}=5)$. In the surface waters of the Tuamotu Archipelago, CharpyRoubaud et al. (1990) measured average $\mathrm{NO}_{2}^{-}+\mathrm{NO}_{3}^{-}$ concentrations of $0.07 \mu \mathrm{M}(\mathrm{SD}=0.04, \mathrm{n}=11)$. All these DIN concentrations are inside the range of $K_{5}$, from 0.01 to $10.3 \mu \mathrm{M}$, for nitrate and ammonium uptake reported by Goldman \& Glibert (1983). Recent studies tend toward lower values in oligotrophic waters. Indeed, a certain degree of physiological adaptation has been found for nutrient $K_{\mathrm{s}}$ controlling phytoplankton. $K_{\mathrm{s}}$ values of short-term nutrient uptake are generally much larger than the corresponding half-saturation of long-term (steady-state) uptake and growth. (Morel 1987). In oligotrophic surface waters of the North Atlantic, $K_{5}$ for $\mathrm{NO}_{3}{ }^{-}$and $\mathrm{NH}_{4}{ }^{+}$uptake were as low as 0.02 to $0.03 \mu \mathrm{M}$ (Harrison et al. 1996). In the oligotrophic tropical Pacific, Lindley et al. (1995) admitted a phytoplankton limitation for DIN $\leq 0.5 \mu \mathrm{M}$. Finally, the DIN concentrations that we measured are close or below these $K_{5}$ values for $N$ uptake and a limitation by $\mathrm{N}$ is therefore expected. 
The average $\mathrm{PO}_{4}{ }^{++}$concentration we measured $(0.21 \mu \mathrm{M}$, Table 1) is much higher than the surface $\mathrm{PO}_{4}{ }^{++}$concentrations (from undetectable to $0.09 \mu \mathrm{M}$ ) reported for the surface waters of the Central North Pacific by Eppley et al. (1973) and Perry \& Eppley (1981) and for the Central South-West Pacific by Le Borgne et al. (1995, 1997). $\mathrm{PO}_{4}^{++}$concentrations like ours have been measured in the surface Pacific at the longitude of the Tuamotu Archipelago: on average $0.39 \mu \mathrm{M}$ ( $\mathrm{SD}=0.11, \mathrm{n}=13$ ) at $12^{\circ} \mathrm{S}$ by Garside (US JGOFS data system: nutrients; http://www1.whoi.edu/ jgofs.html, with permission), $0.12 \mu \mathrm{M}$ at $15^{\circ} \mathrm{S}$ (SD = $0.06, \mathrm{n}=6$ ) by Raimbault et al. (1999) and 0.20 to $0.23 \mu \mathrm{M}$ at $15^{\circ}$ to $16^{\circ} \mathrm{S}$ by Reverdin et al. (1991). In the Tuamotu Archipelago oceanic waters, Charpy-Roubaud et al. (1990) reported $\mathrm{PO}_{4}^{++}$average concentrations of $0.33 \mu \mathrm{M}(\mathrm{SD}=0.10, \mathrm{n}=33)$ while Rancher \& Rougerie (1995) reported an average of $0.15 \mu \mathrm{M}$ (SD = $0.05 \mu \mathrm{M}, \mathrm{n}=5$ ). Such concentrations are close to the $K_{\mathrm{s}}$ for P uptake of 0.14 to $0.18 \mu \mathrm{M}$ in the oligotrophic Central North Pacific (Perry \& Eppley 1981) and, therefore, $\mathrm{P}$ is a potential limiting nutrient.

Our mean $\mathrm{SiO}_{2}$ concentrations (1.03 $\mu \mathrm{M}$, Table 1$)$ are in the range of the concentrations $(0.4$ to $1.6 \mu \mathrm{M})$ reported for surface waters of Central South and North Pacific by Eppley et al. (1973), Perry \& Eppley (1981) and Garside (JGOFS data system: nutrients). In the surface waters of the Tuamotu Archipelago, Charpy-Roubaud et al. (1990) observed Si concentrations identical to ours (mean $=1.08, \mathrm{SD}=0.5, \mathrm{n}=19$ ). $\mathrm{A}$ wide range of $K_{\mathrm{s}}$ for $\mathrm{Si}$ uptake by diatoms, from 0.3 up to $22 \mu \mathrm{M}$, was reported by Brzezinski \& Nelson (1996). However, from the data of Nelson \& Brzezinski (1990), Brzezinski \& Nelson (1996) and Nelson \& Dortch (1996), we may deduce a reasonable limit of $1.5 \mu \mathrm{M}$ under which the growth of natural assemblages of diatoms should be limited. Our mean $\mathrm{SiO}_{2}$ concentration is under this threshold (Table 1). This should be the cause of the scarcity of diatoms in the Tuamotu oceanic waters dominated by non-siliceous taxa of Prochlorococcus and Synechococcus (Charpy \& Blanchot 1998). Such a limitation of diatoms by Si was evidenced in other oligotrophic areas (Nelson \& Brzezinski 1990, Brzezinski \& Nelson 1996).

Results discussed above indicate a potential limitation of phytoplankton by N, P and Si. Nutrient atomic ratios can be used to determine the most limiting nutrient (Goldman et al. 1979). Measured DIN:P-PO ${ }_{4}^{++}$ ratios (on average 0.14 at:at, Table 1) are well below the optimal Redfield ratio of 16 at:at. The observed DIN:Si ratios (Table 1) are far below the value of 1 at:at considered as the optimal uptake ratio for diatoms (Nelson \& Dortch 1996). From these low ratios we may deduce that $\mathrm{N}$ limits more than $\mathrm{P}$ and $\mathrm{Si}$.

Such nitrogen limitation is questionable. Indeed, McCarthy \& Goldman (1979) observed that some phyto- planktonic cells can rapidly and efficiently utilize zooplankton and bacteria excreta before they are physically dispersed to the surrounding media. Therefore other evidence of nutrient limitation is required.

Evidence of nutrient limitation from other kinds of studies in the same area: (1) The maximum quantum yield of photosynthesis, $\varnothing_{\max }$ (maximum carbon dioxide fixed per photons absorbed at subsaturating irradiances), may be lowered by toxins, low temperatures or availability of a nutrient (Rabinowitch 1969, Lindley et al. 1995). $\varnothing_{\max }$ was calculated from $\alpha$, the initial slope of the chlorophyll-normalized primary production-irradiance curve (Pagès pers. comm., on the same samples as ours) and $a_{\mathrm{p}}$ the chlorophyll absorption coefficient $\left(\varnothing_{\max }=\alpha / a_{p}\right)$. For $a_{p}$, we used the mean value of $0.026 \mathrm{~m}^{2} \mathrm{mg}^{-1}(\mathrm{SE}=0.002, \mathrm{n}=8)$ measured at $12^{\circ} \mathrm{S}$, $140^{\circ} \mathrm{W}$ by Lindley et al. (1995). The average $\varnothing_{\max }$ of $0.0069 \mathrm{~mol} \mathrm{C}$ (mol photons) $)^{-1}(\mathrm{n}=6$, maximum of 0.013 ) was well below the operational maximum of 0.06 to $0.10 \mathrm{~mol} \mathrm{C}$ (mol photons) $)^{-1}$ (Cleveland et al. 1989) and indicated photosynthesis limitation. In the surface tropical waters of the Tuamotu Archipelago, phytoplankton metabolism is not submitted to thermal stress, nor toxicity, and nutrient limitation is likely to be the only factor affecting $\varnothing_{\max }$

(2) Picoplankton largely dominates the algal biomass of the Tuamotu surface waters, as seen from the high proportion of chlorophyll in the class size $<3 \mu \mathrm{m}(86 \%$, $\mathrm{SE}=2, \mathrm{n}=11$, Charpy et al. 1997). According to Kiørboe (1993), cells smaller than $100 \mu \mathrm{m}$ in diameter do not profit significantly, in terms of nutrient uptake, from natural water turbulence. However, the small size and, thus, the large surface to volume ratios of autotrophic picoplankton is an even greater advantage over larger algae for nutrient uptake (Chisholm 1992). Therefore, the low nutrient concentrations found in surface waters of the Tuamotu Archipelago are probably a powerful selective force favoring picoplankton. Conversely, the dominance of small cells in these areas may be used as an indicator of nutrient limitation

(3) Nutrient enrichment experiments with N, P, Si, chelators, $\mathrm{Fe}, \mathrm{Mo}, \mathrm{Mn}$ and vitamins were carried out at Sites 1, 4, 6, 7 and 9 (Fig. 1). They allowed us to test the response of phytoplanktonic standing stock to the limiting nutrients and to their combination (Dufour \& Berland 1999). Selected conclusions of these bioassays are reported in Table 2. A noticeable agreement with the conclusions deduced from in situ nutrient concentrations can be observed. Indeed, $\mathrm{N}$ appears clearly as the main limiting nutrient. However, the highest standing stock was obtained with $\mathrm{N}+\mathrm{P}$ enrichments (data shown in Dufour \& Berland 1999). This observation is consistent with a view that both $\mathrm{N}$ and $\mathrm{P}$ are in relatively short supply, so that enrichment by one nutrient without the other produces only a brief growth 
Table 2. Nutrient controls according to in situ concentrations (this study) and to bioassays (Dufour \& Berland 1999)

\begin{tabular}{|c|c|c|c|c|c|}
\hline Site & In situ & Bioassay & Site & In situ ${ }^{\mathrm{a}}$ & Bioassay \\
\hline 1 & $\mathrm{~N}>\mathrm{P}>\mathrm{Si}$ & $\mathrm{N}>\mathrm{P}$ & 7 & $\mathrm{~N}>\mathrm{P}>\mathrm{Si}$ & $\mathrm{N}>\mathrm{P}>\mathrm{Si}$ \\
\hline 2 & $N>S i$ & & 8 & $\mathrm{~N}>\mathrm{P}>\mathrm{Si}$ & \\
\hline 3 & $N>S i$ & & 9 & $\mathrm{~N}>\mathrm{P}>\mathrm{Si}$ & $N>P$ \\
\hline 4 & $N>P$ & $N=P$ & 10 & $\mathrm{~N}>\mathrm{P}>\mathrm{Si}$ & \\
\hline 5 & $N>P$ & & 11 & $\mathrm{~N}>\mathrm{P}>\mathrm{Si}$ & \\
\hline 6 & $\mathrm{~N}>\mathrm{P}>\mathrm{Si}$ & $N>P$ & 12 & $N>S i$ & \\
\hline \multicolumn{6}{|c|}{ 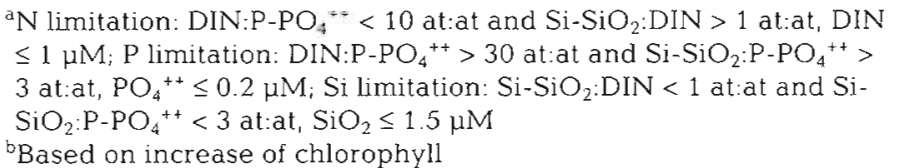 } \\
\hline
\end{tabular}

depleted organic compounds by the phytoplankton should continue to promote this situation. On the other hand, Torréton et al. (1998) observed, in one site of the Tuamotu Archipelago ocean, a positive effect of $\mathrm{NH}_{4}{ }^{+}$ addition on bacterial production. This result, together with the knowledge of nutrient competition between bacterioplankton and phytoplankton, reinforces our hypothesis of $N$ limitation of phytoplankton.

Summary and conclusions. Results of the in situ nutrient concentration measurements and of the 4 other approaches have different significances. The low quantum yield of photosynthesis and the small size of phytoplankton account for a nutrient control. The in situ nutrient concentrations which are indicative

enhancement until the depletion of the other nutrient occurs. Si addition increased phytoplankton standing stock only when $\mathrm{N}$ and $\mathrm{P}$ requirements were preliminarily satisfied. Natural concentrations of chelators, vitamins, Mo, Mn and Fe were sufficient to support increases of phytoplankton standing stock induced by $\mathrm{N}$ and $\mathrm{P}$ additions and therefore were not limiting. $\mathrm{A}$ source of these nutrients could originate from the atolls. Indeed Dufour \& Berland (1999) did not observe such limitation by these nutrients in atoll lagoons. Recently, Lindley et al. (1995) speculated Fe and N colimitation at $12^{\circ} \mathrm{S}, 140^{\circ} \mathrm{W}$ in the oligotrophic Central Pacific some degree north and outside of the Tuamotu Archipelago. However, it appears that iron enrichment stimulates the net growth of microphytoplankton or nanophytoplankton but not of cyanobacteria dominated picophytoplankton which can compensate for growth-limiting levels of iron by producing extracellular siderophores (Wilhelm et al. 1996). Indeed, a lack of $\mathrm{Fe}$ limitation is consistent with the observation that cyanobacteria dominate in the area under study (Charpy \& Blanchot 1998).

(4) It is now well established that bacteria make up more of the oligotrophic ocean biomass than phytoplankton do (Cho \& Azam 1990, Dufour \& Torréton 1996). Bacterial carbon at the 12 sites sampled (Fig. 1) was 2.8 times the phytoplankton carbon ( $\mathrm{SD}=0.9, \mathrm{n}=$ 12. Torréton pers. comm.). On the other hand, it was shown that the $\mathrm{N}: \mathrm{C}$ ratio is higher in bacteria than in phytoplankton (Goldman et al. 1987). Therefore, a large part of the $N$ standing stock is immobilized by bacteria and is not available for phytoplankton. Moreover, Wheeler \& Kirchman (1986) showed that bacteria are able to compete successfully with phytoplankton for $\mathrm{NH}_{4}{ }^{+}$. Therefore, under conditions of extremely low concentrations of DIN (and not of $\mathrm{PO}_{4}{ }^{++}$, as seen above), bacteria are likely to maintain the phytoplankton in a state of $\mathrm{N}$ limitation. The excretion of $\mathrm{N}$ - of the nutrient uptake limitation and the in vitro enrichment experiments which identify the nutrients that limit the phytoplanktonic standing stock agree with $\mathrm{N}$ limitation (Table 2). Therefore, other sources of $N$, such as $\mathrm{N}_{2}$ fixation (Smith 1984), dissolved organic $\mathrm{N}$ (Bonin \& Maestrini 1981) and rain (Prospero \& Savoie 1989), appear insufficient to supply the phytoplankton $\mathrm{N}$ requirements. The high bacterial biomass and the $\mathrm{N}$ limitation of bacterial production confirm the $\mathrm{N}$ deficiency. Even if phosphate is not totally exhausted in situ, $\mathrm{P}$ is the second limiting nutrient as evidenced by the synergistic effect of $\mathrm{N}+\mathrm{P}$ enrichments. Silicon concentrations appear most often under the threshold level for siliceous taxa. However, $\mathrm{Si}$ is less limiting than $\mathrm{N}$ as evidenced by DIN:Si. Si additions increase phytoplankton standing stock when $\mathrm{N}$ and $\mathrm{P}$ requirements are preliminarily satisfied, probably inducing a shift from picoplankton to larger diatoms. Natural concentrations of vitamins, Mo, Mn, Fe and chelators are sufficient to support the increase of phytoplankton standing stock induced by $\mathrm{N}$ and $\mathrm{P}$ additions and therefore are not limiting. A lack of Fe limitation is consistent with the dominance of cyanobacteria but contradicts the $\mathrm{N}$ and $\mathrm{Fe}$ simultaneous limitation speculated by Lindley et al. (1995) for the oligotrophic South Pacific Ocean. Nevertheless, if not limiting the phytoplankton stock, Fe and other micronutrients may control the phytoplankton taxonomic composition (Bonin \& Maestrini 1981, Zettler et al. 1996).

The synthesis of these different studies gives a synoptic view of phytoplanktonic nutrient control. It is a further step towards knowledge of the biochemical functioning of the oligotrophic Central South Pacific. It also should be used as a reference to studies considering the functioning of the 77 lagoons of the Tuamotu Archipelago which are fuelled by the oceanic water of the South Pacific central gyre (Dufour \& HarmelinVivien 1997). 
Acknowledgements. This research was supported by the Institut Français de Recherches pour le Développement (IRD) and the Programme National Récifs Coralliens (PNRCO) in the frame of the Typatoll program. We would like to thank the crew of the RV 'Alis'. We appreciate the helpful suggestions of M. C. Bonin, A. Le Bouteiller, R. Le Borgne, M. Rodier and 4 anonymous reviewers.

\section{LITERATURE CITED}

Bonin DJ, Maestrini SY (1981) Importance of organic nutrients for phytoplankton growth in natural environments. Implications for algal species succession. Can Bull Fish Aquat Sci 210:279-291

Brzezinski MA, Nelson DM (1996) Chronic limitation of silicic acid uptake rates in the western Sargasso Sea. Deep-Sea Res I 43:437-453

Charpy L, Blanchot J (1998) Photosynthetic picoplankton in French Polynesian atoll lagoons: estimation of taxa contribution to biomass and production by flow cytometry. Mar Ecol Prog Ser 162:57-70

Charpy L, Dufour P, Garcia N (1997) Particulate organic matter in sixteen Tuamotu atoll lagoons (French Polynesia). Mar Ecol Prog Ser 151:55-65

Charpy-Roubaud CJ, Charpy L, Cremoux JL (1990) Nutrient budget of the lagoonal waters in an open central south Pacific atoll (Tikehau, Tuamotu, French Polynesia). Mar Biol 107:67-73

Chisholm SW (1992) Phytoplankton size. In: Falkowski PG, Woodhead AD (eds) Primary production in the sea. Plenum Press, New York, p 213-237

Cho BC, Azam F (1990) Biogeochemical significance of bacterial biomass in the ocean's euphotic zone. Mar Ecol Prog Ser 63:253-259

Cleveland JS, Perry MJ, Kiefer DA, Talbot MC (1989) Maximum quantum yield of photosynthesis in the northwestern Sargasso Sea. J Mar Res 47:869-886

Droop MR (1983) 25 years of algal growth kinetics. A personal view. Bot Mar 26:99-112

Dufour P, Berland B (1999) Nutrient control of phytoplanktonic biomass in atoll lagoons and Pacific ocean waters: studies with factorial enrichment bioassays. J Exp Mar Biol Ecol 234:147-166

Dufour P, Harmelin-Vivien M (1997) A research program for a typology of atoll lagoons: strategy and first results. Proc 8th Int Coral Reefs Symp, Panama 1:843-848

Dufour P. Torréton JP (1996) Bottom-up and top-down control of bacterioplankton from eutrophic to oligotrophic sites in the tropical northeastern Atlantic Ocean. Deep-Sea Res I 43:1305-1320

Eppley RW, Venrick EL, Mullin MM (1973) A study of plankton dynamics and nutrient cycling in the central gyre of the North Pacific Ocean. Limnol Oceanogr 18: $534-551$

Fisher TR, Harding LW Jr, Stanley DW, Ward LG (1988) Phytoplankton, nutrients and turbidity in the Chesapeake, Delaware and Hudson estuaries. Estuar Coast Shelf Sci 27:61-93

Goldman JC, Caron DA, Dennett MR (1987) Regulation of growth efficiency and ammonium regeneration in bacteria by substrate $\mathrm{C}: \mathrm{N}$ ratio. Limnol Oceanogr 32: $1239-1252$

Goldman JC, Glibert PM (1983) Kinetics of inorganic nitrogen uptake by phytoplankton. In: Carpenter EJ, Capone DG (eds) Nitrogen in the marine environment. Academic Press, New York, p 233-274
Goldman JC, MCCarthy JJ, Peavy DG (1979) Growth rate influence on the chemical composition of phytoplankton in oceanic waters. Nature 279:210-215

Harrison WG, Harris LR, Irwin BD (1996) The kinetics of nitrogen utilization in the oceanic mixed layer nitrate and ammonium interactions at nanomolar concentrations. Limnol Oceanogr 41:16-32

Howarth RW (1988) Nutrient limitation of net primary production in marine ecosystems. Annu Rev Ecol Syst 19:89-110

Kiørboe T (1993) Turbulence, phytoplankton cell size and the structure of pelagic food webs. Adv Mar Biol 29:1-72

Koroleff F (1969) Revised version of 'Direct determination of total nitrogen in natural waters by means of persulfate oxydation' Int Counc Explor Sea, CM 1969/C: 8

Le Borgne $R$, Brunet $C$, Eldin $G$, Radenac $M H$, Rodier $M$ (1995) Campagne océanographique FLUPAC à bord du N.O. Atalante, 23 septembre au 29 octobre 1994. Recueil des données. Arch Sci Mer Oceanogr 1:340 p

Le Borgne R, Rodier M, Bouteiller A, Kulbicki M (1997) Plankton biomass in an open atoll lagoon. Uvea, New Caledonia. J Exp Mar Biol Ecol 212:187-210

Lindley ST, Bidigare RR, Barber RT (1995) Phytoplankton photosynthesis parameters along $140^{\circ} \mathrm{W}$ in the equatorial Pacific. Deep-Sea Res II 42:441-463

MCCarthy JJ, Goldman JC (1979) Nitrogenous nutrition of marine phytoplankton in nutrient-depleted waters. Science 203:670-672

Morel FMM (1987) Kinetics of nutrient uptake and growth in phytoplankton. J Phycol 23:137-150

Mullin JB, Riley JP (1955) The spectrophotometric determination of silicate-silicon in natural waters with special reference to sea water. Anal Chim Acta 12:162-170

Murphy J, Riley JP (1962) A modified single solution method for the determination of phosphate in natural waters. Anal Chim Acta 27:31-36

Nelson DM, Brzezinski MA (1990) Kinetics of silicic acid uptake by natural diatom assemblages in two Gulf Stream warm-core rings. Mar Ecol Prog Ser 62:283-292

Nelson DM, Dortch Q (1996) Silicic acid depletion and silicon limitation in the plume of the Mississippi River: evidence from kinetic studies in spring and summer. Mar Ecol Prog Ser 136:163-178

Perry MJ, Eppley RW (1981) Phosphate uptake by phytoplankton in the central North Pacific Ocean. Deep-Sea Res 28A:39-49

Prospero JM, Savoie DL (1989) Effect of continental sources on nitrate concentrations over the Pacific Ocean. Nature 339:687-689

Rabinowitch EG (1969) Photosynthesis. Wiley \& Sons, New York Raimbault P, Slawyk G, Boudjellal B, Coatanoan C, Conan P, Coste B, Garcia N, Moutin T, Pujo-Pay M (1999) Biomass, new production and export in the Equatorial Pacific: evidence for intense nitrogen recycling. J Geophys Res 104 $3341-3356$

Rancher J, Rougerie F (1995) L'environnement océanique de l'archipel des Tuamotu (Polynésie Française). Oceanol Acta 18:43-60

Reverdin G, Morlière A, Eldin G (1991) Alizé 2: campagne océanographique trans-Pacifique. Rapport interne 91/13 LODYC, Univ P \& M Curie, Paris

Smith SV (1984) Phosphorus versus nitrogen limitation in the marine environment. Limnol Oceanogr 29:1149-1160

Torréton JP, Talbot V, Garcia N (1998) Nutrient stimulation of bacterioplankton growth in Tuamotu atoll lagoons. 1998 Ocean Sciences Meeting AGU/ASLO (Feb 98, San Diego, USA). EOS Trans Am Geophys Union 79(1):OS54 (abstract) 
Tréguer P, Le Corre P (1975) Manuel d'analyses des sels nutritifs dans l'eau de mer. Laboratoire d'Ocëanographie Chimique, Université de Bretagne Occidentale, Brest

Wheeler PA, Kirchman DL (1986) Utilization of inorganic and organic nitrogen by bacteria in marine systems. Limnol Oceanogr 31:998-1009

Wilhelm SW, Maxwell DP, Trick CG (1996) Growth, iron requirements and siderophore production in iron-

Editorial responsibility: Otto Kinne (Editor),

Oldendorf/Luhe, Germany limited Synechococcus PCC 7002. Limnol Oceanogr 41 $89-97$

Wood EPK, Armstrong FAJ, Richards FA (1967) Determination of nitrate in seawater by cadmium copper reduction to nitrite. J Mar Biol Assoc UK 47:23-31

Zettler ER, Olson RJ, Binder BJ, Chisholm SW, Fitzwater SE, Gordon RM (1996) Iron-enrichment bottle experiments in the equatorial Pacific responses of individual phytoplankton cells. Deep-Sea Res II 43:101.7-1029

Submitted: September 14, 1998; Accepted: February 1, 1999 Proofs received from author(s): March 29, 1999 